\title{
Effect of Storage Conditions on Physicochemical Characteristics and Phenolic Compounds of Eggplant (Solanum melongena L.)
}

\author{
Efecto de las Condiciones de Almacenamiento sobre las Características Físicoquímicas y \\ Contenido de Compuestos Fenólicos de Berenjena (Solanum melongena L.)
}

Jose Barragán ${ }^{1}$; Arlet Franco²; Jéssica López ${ }^{3}$; Carmen Perez-Cervera ${ }^{4}$

\begin{abstract}
ARTICLE DATA
Agroindustrial Engineering, Universidad Pontificia Bolivariana, Montería, Colombia, jose_barragan95@ hotmail.com

Teacher, Ph.D. Universidad Pontificia Bolivariana, Montería, Colombia, arlet.franco@upb.edu.co

Teacher, Ph.D. Pontificia Universidad Católica de Valparaíso, Valparaíso, Chile, j.lopez.pasten@gmail.com

Teacher, Ph.D. Universidad Pontificia Bolivariana, Montería, Colombia, carmenelena.perez@upb.edu.co
\end{abstract}

Citar: Barragan, J.; Franco, A.; López, J.; Perez-Cervera, C. (2019). Effect of Storage Conditions on Physicochemical Characteristics and Phenolic Compounds of Eggplant (Solanum melongena L.). Revista de Ciencias Agrícolas. 36(2): 5-16. https://doi.org/10.22267/rcia.193602.114

Received: August 142018.

Accepted: April 112019.

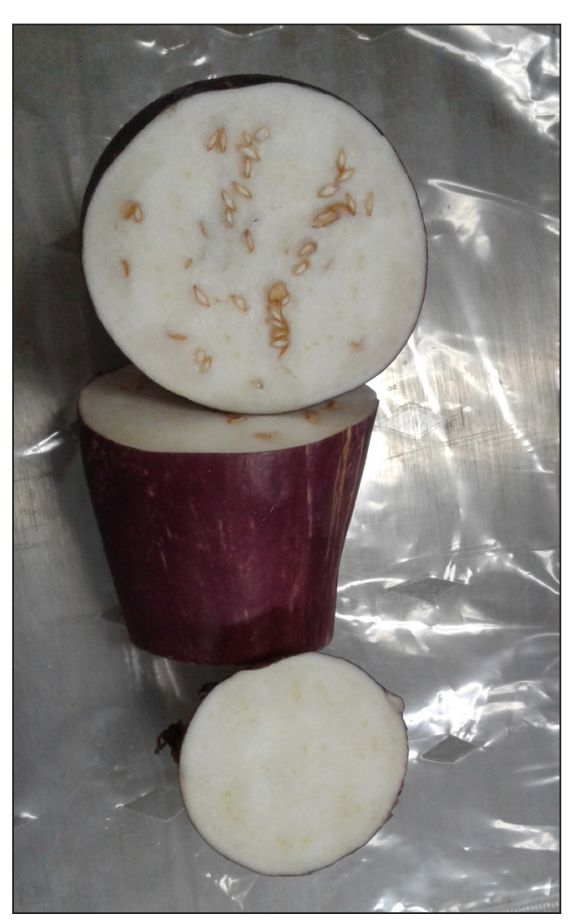

ABSTRACT

High demand for fresh fruit and vegetables requires the implementation of techniques to extend the shelf life of these highly perishable products. A widely used method for this purpose is the refrigeration; however, it is known that most of the vegetables preserved in this way evidence chilling injury signs during storage. Eggplants cv $\mathrm{C} 029$ recently harvested were stored at $13^{\circ} \mathrm{C}$ packed into low-density polyethylene bags either with perforations (PPB), vacuum packaged (VPB), or unpacked during 5, 10,15 and 20 days to evaluate the effect of chilling on physicochemical characteristics and visual appearance. Unpacked Eggplants presented remarkable chilling injury symptoms, losing its commercial quality before 10d of storage. Fruit stored in VPB showed discoloration affecting visual appearance but maintains the phenolic compounds and avoided pulp and seeds browning. Eggplants packed in PPB showed the best results in this work, preserving overall characteristics during $15 \mathrm{~d}$.

Keywords: Chilling injury; commercial quality; low-density polyethylene (LPDE) bags; vacuum packaging (VPB).

\section{RESUMEN}

La demanda de los mercados globales por productos frescos requiere la implementación de métodos que permitan prolongar su vida de útil, especialmente en el caso de frutas y vegetales por ser altamente perecederos. Un método de conservación ampliamente utilizado es la refrigeración, sin embargo, la mayoría de los vegetales preservados empleando este método presentan señales de daño por frio durante el almacenamiento. Berenjenas cv C029 recién cosechadas fueron almacenadas a $13^{\circ} \mathrm{C}$, empacadas en bolsas de polietileno de baja densidad con perforaciones (PPB), vacío (VPB) y control, durante 5, 10, 15 y 20 d, para evaluar el efecto de la refrigeración sobre sus características físico químicas y visuales. Las muestras de control presentaron considerables síntomas de daño por frio, perdiendo su calidad comercial antes de $10 \mathrm{~d}$ de almacenamiento. Frutas almacenadas en VPB presentaron pérdida de color, afectando negativamente su apariencia visual, no obstante, preservando su contenido de compuestos fenólicos y evitando el pardeamiento de las semillas. Berenjenas almacenadas en PPB presentaron los mejores resultados en este trabajo, manteniendo sus características organolépticas durante $15 \mathrm{~d}$.

Palabras clave: Daño por frio; calidad comercial; polietileno de baja densidad (LPDE); empaque al vacío (VPB). 


\section{INTRODUCTION}

The Eggplant (Solanum melongena L.) is a common and popular vegetable, mainly used as a cooking ingredient for dishes all over the world. Its annual production is around 51.3 million $\mathrm{t}$ (FA0, 2017). Although many eggplant cultivars vary in color, size, and shape of the fruit (García-Salas et al., 2014), they have a common high content of anthocyanins and polyphenols which are known as bioactive compounds and defined as secondary metabolites of plants. They are usually involved in defense mechanisms against ultraviolet radiation and pathogen aggression (Cao et al., 1997; Manach et al., 2004).

Anthocyanins are natural pigments responsible for many of the orange, red, blue, violet, and magenta colors in plants (Francis, 2000). Polyphenolic compounds may be associated with several carbohydrates and organic acids, which are derived from benzoic and cinnamic acids (Manach et al., 2004). Chlorogenic acid belongs to hydroxycinnamic ones and is the most abundant phenol acid in eggplants, with a reported concentration between 600 and $660 \mathrm{mg} / \mathrm{L}$ (Manach et al., 2004).

Recently increase in consumption of the eggplant fruit in the world (FA0, 2017) is mainly associated with health beneficial effects derived from its bioactive compounds, responsible for its antioxidant capacity (Stommel and Whitaker, 2003). Several research publications are reporting the health benefits related to the phenolic compounds and flavonoids extracted from eggplant which are associated with the reduction of risk of cardiovascular diseases, some forms of cancer and DNA damages and mutations (Cao et al., 1997; Huang et al., 2004; Nisha et al., 2009; Sudheesh et al., 1999; Gürbüz et al., 2018; Sukprasansap et al., 2019; Yamaguchi et al., 2019). According to Cao et al. (1997) eggplant is ranked among the 10 vegetables with the highest oxygen radical absorbance capacity (ORAC).

However, eggplant commercialization is a challenge for local farmers due to its reduced shelf life. Eggplant as a fruit is a plant-living organ, with a series of ongoing changes on physical, chemical, biochemical, and sensorial attributes during its growth. When the fruit is harvested water and nutrients supplied from the plant are interrupted, but respiration and other metabolic reactions continue (Montero-Calderón and Cerdas-Araya, 2012). Therefore it takes place a gradual deterioration of the food during storage as a result of physical or chemical changes (Singh and Singh, 2005). The most important cause of deterioration of fruit and vegetables during storage is the respiration rate, which is inversely related to the shelf life of fresh products (Berk, 2009). Eggplant fruit deterioration during long term storage is associated with calyx discoloration and pulp browning caused by phenolic compounds oxidation (Cantwell and Suslow, 2000; Massolo et al., 2011; Mishra et al., 2013).

The shelf life of fruit and vegetables could be extended, controlling their rate of respiration by refrigeration or through the combination of refrigeration and packaging materials (Singh and Singh, 2005). Low-temperature storage is effective for the preservation of fresh products as vegetables, reducing browning reactions, and delaying fruit deterioration (Massolo et al., 2011). Nevertheless, postharvest handling of eggplants is challenging due to their susceptibility to chilling injury which limits their postharvest life. As chilling sensitive, eggplant fruit should not be stored for long periods below $10^{\circ} \mathrm{C}$. Chilling injury includes pitting, surface discoloration, browning of seeds and pulp tissue, and water loss (Cantwell and Suslow, 2000; Concellón et al., 2007). Visible signs of water loss are reduction of surface sheen, skin wrinkling, spongy flesh, and browning of the calyx (Cantwell and Suslow, 2000). 
The chilling injury and water loss can be reduced by storing eggplant in polyethylene bags or polymeric film overwraps (Cantwell and Suslow, 2000) and there are several reports available regarding positive effects of packaging materials on organoleptic characteristics of food products. The objective of this work was to evaluate the effect of refrigeration on physicochemical characteristics and phenolic compounds of eggplant (Solanum melongena L.) cultivar variety C029, packed in low-density polyethylene (LDPE) bags, to explore alternatives to preserve fruit quality and extend its shelf life.

\section{MATERIALS AND METHODS}

Raw material and storage conditions. Fresh eggplants (S. melongena) cv. C029 were purchased in a local market in the city of Cereté (Córdoba, Colombia). The fruit was selected, washed, disinfected by immersion in chlorinated water $\left(50 \mathrm{mg} \mathrm{kg}^{-1}\right)$, air-dried, and randomly packed in groups of three fruit in low-density polyethylene (LDPE) bags. Two different bag types were used: perforated polyethylene bags $(88 \mu \mathrm{m}$ thick) (PPB) and vacuum polyethylene bags $(88 \mu \mathrm{m}$ thick $)$ (VPB). Packed eggplants were stored at $13^{\circ} \mathrm{C}(85-$ $90 \% \mathrm{RH}$ ) for $0,5,10,15$ and 20 days. The control sample was stored under the same refrigeration conditions without being packaged. Experiments were performed in triplicate.

\section{Evaluation of the effect of refrigeration on physicochemical characteristics.}

Moisture content. The moisture content was determined according to the Association of Official Agricultural Chemists (AOAC) methodology no. 934.06 (AOAC, 2005), using an oven (WTC BINDER, Germany) at $90^{\circ} \mathrm{C}$ until they reached a constant weight. Results were expressed as the percentage of water content on a wet weight basis (w.b.).
Weight loss. Eggplant fruit samples under defined conditions (PPB, VPB, and control) were weighed at the beginning of the experiment and during storage. The weight loss (WL) was calculated as:

$$
W L=\left[\frac{W_{i}-W_{f}}{W_{i}}\right] \times 100
$$

Where $W_{i}$ the initial sample is weight and $W_{f}$ is the final sample weight. Results were expressed as a percentage of weight loss. Nine fruits were evaluated for each condition.

Determination of $\mathbf{p H}$ and acidity. The $\mathrm{pH}$ was measured using a pH meter 744 (Metrohm, Switzerland). Titrable acidity, expressed as ascorbic acid (\%) was determined by the adapted AOAC methodology no. 942.15 (AOAC, 2005).

Evaluation of refrigeration effect on fruit physical appearance. Packed and unpacked fruit under refrigeration conditions were visually inspected. Internal and external appearances were evaluated at intervals of five days and pictures were taken.

Browning in pulp tissue. Changes of pulp tissue color were evaluated using a Colorimeter model CR-10 (Konica Minolta, Japan) by determination of the parameters $\mathrm{L}^{*}$. The color parameter $\mathrm{L}^{*}$ indicates the lightness of color $(0=$ black and 100 = white). Readings were taken soon after slicing the central section of each fruit. All measurements were done on two fruits from each condition and results were expressed as $L_{0}$, where values higher than 86 describe whitish pulp, values between 81 and 82 reports only seed browning, lightness around to 78 indicates an incipient browning of seeds and pulp, whereas values below 73 denote considerable browning of seed and pulp.

Determination total phenolic content. The total phenolic content (TPC) was determined colorimetrically using Folin-Ciocalteu (FC) reagent according to Zaro et al. (2014) with some 
modifications. Five gram of eggplant pulp tissue was grounded in a mortar and added to $20 \mathrm{~mL}$ ethanol. The suspension was vortexed, extracted during $30 \mathrm{~min}$, and then centrifuged at 12,000 $\mathrm{x} g$ for $10 \mathrm{~min}$. For TPC determination $250 \mu \mathrm{L}$ of Folic-Ciocalteu reagent diluted 1:1 in water were pipetted into the test tubes containing $80 \mu \mathrm{L}$ ethanolic extracts and $920 \mu \mathrm{L}$ water. After $3 \mathrm{~min}$, $1,250 \mu \mathrm{L} \quad \mathrm{Na}_{2} \mathrm{CO}_{3}$ solutions $(200 \mathrm{mg} / \mathrm{mL})$ were added. The reaction mixture was vortexed and then incubated for $30 \mathrm{~min}$. The absorbance was measured at $760 \mathrm{~nm}$ by using a spectrophotometer Spectroquant ${ }^{\circledR}$ Pharo 300 (Merck KGaA, Darmstadt, Germany) and compared with a previously prepared Gallic Acid calibration curve. Results were expressed as Gallic Acid Equivalent (GAE) $\mathrm{mg} \cdot \mathrm{kg}^{-1}$ on a dry weight basis (d.b).

Statistical analysis. All analyses were run in duplicate. ANOVA tests were performed to identify mean differences using JMP 9.0.1 statistical software (SAS Institute Inc., Cary, NC). The LSD Fisher test was considered for this purpose with a significance level of 5\% (alpha=0.05).

\section{RESULTS AND DISCUSSION}

\section{Effect of refrigeration on physicochemical characteristics.}

Moisture content. Changes in the moisture content of eggplant fruit during storage at a temperature of $13^{\circ} \mathrm{C}$ are shown in Table 1 . Moisture loss for packaged samples was negligible up to the fifth day and none of the treatments presented significant differences regarding the control sample. After ten days it was possible to evidence significant differences between unpacked sample (control) and samples packed in perforated polyethylene bags (PPB). Compared with the PPB treatment, moisture loss was observed for vacuum polyethylene bags (VPB) treatment and control samples between the fifteenth and twentieth day. Although VPB showed the highest moisture content until the fifth day, it gradually decreased until the twentieth day. Significant differences for each evaluation period were evidenced. PPB treatment presented the best results related to moisture content preservation.

Table 1. Effect of packaging condition and storage at $13^{\circ} \mathrm{C}$ on the moisture content of eggplant.

\begin{tabular}{|c|c|c|c|c|c|c|}
\hline \multicolumn{7}{|c|}{ Moisture content ( $\%$ w.b.) } \\
\hline \multicolumn{7}{|c|}{ Storage time (d) } \\
\hline & & $\mathbf{0}$ & 5 & 10 & 15 & 20 \\
\hline \multirow{3}{*}{ 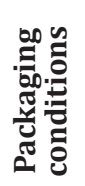 } & Control & $93.72 \pm 0.04^{\mathrm{a}}$ & $92.66 \pm 0.93^{\mathrm{a}}$ & $91.98 \pm 0.46^{\mathrm{a}}$ & $90.76 \pm 0.22^{\mathrm{a}}$ & $89.90 \pm 0.25^{\mathrm{a}}$ \\
\hline & РPB & $93.72 \pm 0.04^{a}$ & $93.13 \pm 0.25^{\mathrm{a}}$ & $92.89 \pm 0.23^{b}$ & $92.74 \pm 0.29^{b}$ & $92.54 \pm 0.11^{b}$ \\
\hline & VPB & $93.72 \pm 0.04^{\mathrm{a}}$ & $93.48 \pm 0.04^{\mathrm{a}}$ & $92.81 \pm 0.07^{\mathrm{ab}}$ & $91.58 \pm 0.08^{\mathrm{a}}$ & $90.26 \pm 0.38^{\mathrm{a}}$ \\
\hline
\end{tabular}

Results are mean \pm SD. Different superscript letters in the same column indicate that values were significantly different $(p<0.05)$. 
Even though eggplant fruit showed moisture content diminution, the highest weight loss (WL) was only $4.1 \%$, showed by control samples, whereas VPB and PPB presented 3.7\% and 1.3\% (Figure 1).Concellón et al. (2012) reported a total WL of 4.2\% for eggplant fruits cv Lucía packed into plastic trays and covered with perforated PVC, stored at $10^{\circ} \mathrm{C}$ during $14 \mathrm{~d}$. Although the storage temperature defined in this work was higher than employed by Concellón et al. (2012), the weight loss presented by cv C029 was lower, which could be associated with the calyx size, which is shorter than the other eggplant varieties. According to Díaz-Pérez (1998), the rate of fruit water loss was highly correlated with the calyx area ratio for Classic variety and depending on varieties, which can lose up to $65 \%$ of its water content by the calyx. Dehydration processes could be accompanied by reduction on the surface sheen, fruit softening, and shriveling and epicarp shrinkage (Cantwell and Suslow, 2000) as a consequence of loss turgidity by fruit cells (Montero-Calderón and Cerdas-Araya, 2012). The Eggplant fruit stored at refrigeration conditions was susceptible to present physicochemical changes associated with lowtemperature exposition, which affected quality attributes like color, appearance, and texture. Similar effects of refrigeration on eggplants have been previously reported for different eggplant varieties as Money Maker No. 2 (Concellón et al., 2007), Lucía (Concellón et al., 2012), Monarca and Perla Negra (Zaro et al., 2014).

Weight loss. Weight losses observed by the eggplants packaged under PPB and VPB conditions and the control samples stored at $13^{\circ} \mathrm{C}$ were compared. Control samples exhibited higher weight losses than the other packaged samples and this trend gradually increased during storage (Figure 1). At the end of the storage period (20d), control eggplants lost $16 \%$ of its weight, whereas packaged fruitatPPB and VPB conditions presented weight loss of 14 and $2 \%$, respectively. These data would indicate an extension of eggplants shelf-life, especially at vacuum conditions. According to this, VPB treatment reduced weight loss in eggplant fruit during $20 \mathrm{~d}$ of storage at $13^{\circ} \mathrm{C}$.

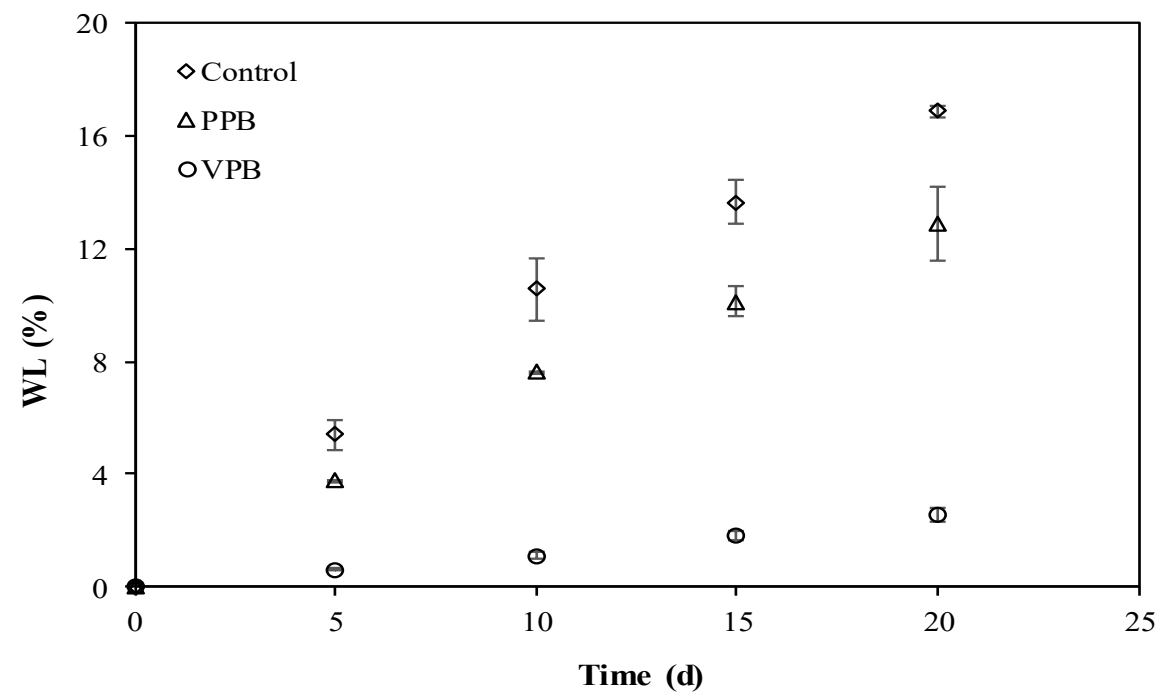

Figure 1. Effect of packaging conditions during storage at $13^{\circ} \mathrm{C}$ on the weight loss (WL) of eggplant fruits. 
In the case of PPB condition and the control samples, the water derived from eggplant respiration was removed by evaporation from the fruit surface, promoting them weight loss. Decreasing of eggplants weight during storage was also reported by Jha et al. (2002) and Concellón et al. (2012) at temperatures between 0 and $20^{\circ} \mathrm{C}$, showing an increase in weight loss rate with storage temperature. For the VPB condition, condensed water remained in the package. Therefore, eggplant fruit under VPB condition presented the lowest weight loss, which is not related to moisture content results because measurement conditions were different.

pH and acidity. The pH and acidity of eggplant at PPB and VPB conditions and control samples during storage at $13^{\circ} \mathrm{C}$ are shown in Table 2. The $\mathrm{pH}$ increased during storage under the three conditions. After five days, the $\mathrm{pH}$ in the VPB packed sample presented an increase of $6.8 \%$ when compared with the control sample and PPB packed samples. From the tenth day on, all tested treatments showed significant differences above $4.72 \%$. The highest $\mathrm{pH}$ value was reported under the VPB condition.

For control and PPB samples we report a $\mathrm{pH}$ decrease until the fifth day and then it increased until the end of storage. The $\mathrm{pH}$ under VPB conditions exhibited a different behavior, showing a gradual increase during the storage period. This treatment reported the highest $\mathrm{pH}$ values for each measurement. In the case of acidity, it showed an increasing trend for PPB condition and control samples during all the storage time whereas VPB condition presented a gradual decrement during this period. An increase in $\mathrm{pH}$ values during eggplant storage at temperatures between 0 and $30^{\circ} \mathrm{C}$ was also reported by Concellón et al. (2007) and Amanullah et al. (2016). According to this, the $\mathrm{pH}$ value of eggplant fruits increases with storage temperature (Amanullah et al., 2016 and Concellón et al., 2007).

Changes in color. The browning in eggplant fruits is the result of reactions between phenolic compounds and oxidative enzymes owing to cellular disruptions (Massolo et al., 2011), usually related to long term storage and chilling injury and is associated with postharvest quality loss of eggplant fruit (Concellón et al., 2007; Massolo et al., 2011; Pérez-Gilabert \& García-Carmona, 2000). Browning in the pulp tissue and seeds for PPB, VPB, and control samples, described as Lightness $\left(\mathrm{L}_{0}\right)$ is presented in Table 3. According to the established scale, until the $15^{\text {th }}$ day, $\mathrm{L}_{0}$ readings values for PPB and VPB evidenced preservation of white color in pulp and just presented seeds browning at the end of storage Figure 2.

Table 2. Effect of packaging conditions and storage at $13^{\circ} \mathrm{C}$ on the $\mathrm{pH}$ and acidity of eggplant.

\begin{tabular}{|c|c|c|c|c|c|c|c|c|c|c|c|c|c|c|c|c|c|}
\hline \multirow{3}{*}{$\begin{array}{c}\text { Time } \\
\text { storage } \\
\text { (d) }\end{array}$} & \multicolumn{17}{|c|}{ Treatments } \\
\hline & \multirow{2}{*}{\multicolumn{9}{|c|}{$\begin{array}{l}\mathrm{PPB} \\
\mathrm{pH}\end{array}$}} & & Cont & rol & & $\mathbf{P P}$ & & & VPB \\
\hline & & & & & & & & & & \multicolumn{8}{|c|}{ Acidity (\%) } \\
\hline 0 & 5.39 & \pm & $0.03^{\mathrm{Ba}}$ & 5.39 & \pm & $0.03^{\mathrm{Ca}}$ & 5.39 & \pm & $0.03^{\mathrm{Aa}}$ & 0.10 & \pm & $0.00^{\mathrm{Aa}}$ & 0.10 & \pm & $0.00^{\mathrm{Aa}}$ & 0.10 & $\pm 0.00^{\mathrm{Aa}}$ \\
\hline 5 & 5.22 & \pm & $0.06^{\mathrm{Aa}}$ & 5.15 & \pm & $0.02^{\mathrm{Aa}}$ & 5.56 & \pm & $0.01^{\mathrm{Bb}}$ & 0.12 & \pm & $0.14^{\mathrm{Aab}}$ & 0.15 & \pm & $0.01^{\mathrm{Bb}}$ & 0.09 & $\pm 0.01^{\mathrm{Ba}}$ \\
\hline 10 & 5.45 & \pm & $0.01^{\mathrm{BCa}}$ & 5.30 & \pm & $0.01^{\mathrm{Bb}}$ & 5.72 & \pm & $0.01^{\mathrm{Cc}}$ & 0.16 & \pm & $0.01^{\mathrm{Bb}}$ & 0.18 & \pm & $0.01^{\mathrm{BCb}}$ & 0.09 & $\pm 0.00^{\mathrm{Ba}}$ \\
\hline 15 & 5.53 & \pm & $0.01^{\mathrm{Ca}}$ & 5.42 & \pm & $0.03^{\mathrm{Cb}}$ & 5.88 & \pm & $0.01^{\mathrm{Dc}}$ & 0.17 & \pm & $0.01^{\mathrm{Bb}}$ & 0.20 & \pm & $0.01^{\mathrm{cb}}$ & 0.09 & $\pm 0.01^{\mathrm{Ba}}$ \\
\hline 20 & 5.89 & \pm & $0.03^{\mathrm{Da}}$ & 5.73 & \pm & $0.01^{\mathrm{Db}}$ & 5.99 & \pm & $0.01^{\mathrm{Ec}}$ & 0.18 & \pm & $0.02^{\mathrm{Bb}}$ & 0.21 & \pm & $0.00^{\mathrm{Cb}}$ & 0.07 & $\pm 0.01^{\mathrm{Ba}}$ \\
\hline
\end{tabular}

Different capital letters in the same column indicate significant $(p<0.05)$ differences for each packaging condition. Lower case letters in the same row indicate significant $(p<0.05)$ differences between tested packaging treatments. 
The control sample only kept the color whitish until the tenth day and then the seeds were brown, presenting a pulp and seeds at the end of the storage time.

According to these, the results showed a correlation between the visual appearance of pulp tissue and $\mathrm{L}^{*}$, hence, eggplants packed into VPB and recently sliced did not show signs of chilling injury in the pulp tissue, preserving it whitish color up to day $20^{\text {th }}$. Enzymatic browning is mainly related to polyphenol oxidase (PPO), which can act on phenols in the presence of oxygen (Nicolas et al., 1994; Muñoz-Pina et al., 2020).

Although the results were different for each condition, lightness values decreased gradually for all treatments until day $20^{\text {th }}$. Moreover, loss of lightness was more remarkable for control samples and PPB treatment. These results could be associated with PPO activity, which increases at temperatures above $10^{\circ} \mathrm{C}$, as reported by Concellón et al. (2004) for eggplant fruit cv. Money Maker No 2 packed into $\mathrm{PPB}$ stored at 0 and $10^{\circ} \mathrm{C}$. PPO can oxidize phenolic compounds of eggplants and this process has been related to fruit deterioration (Concellón et al., 2004; Das et al., 1997).
Enzymatic browning can be defined as initial enzymatic oxidation of phenols to colored quinones, which subsequently polymerize leading to the appearance of brown pigments (Nicolas et al., 1994; Pérez-Gilabert and García-Carmona, 2000; Muñoz-Pina et al., 2020). This process is more important in vegetables with a high phenol content such as potatoes, apples and eggplants (Matheis and Belitz, 1977; Nicolas et al., 1994; Sakamura and Obata, 1963, Muñoz-Pina et al., 2020).

Skin color changes of eggplant fruit were also reported, they are associated with pigments loss during cold storage at VPB condition, as a consequence of increases on respiration rate and thus ethylene production. Refrigeration is known as a stress-inducing factor on fruit and vegetables, which result in ethylene production (Kacperska, 1997; Concellón et al., 2005); therefore, contact with ethylene can reduce the shelf life of eggplant fruit; Cantwell and Suslow (2000) and Kader (2002), report that moderate and high sensitivity to exogenous ethylene, accompanied by calyx abscission and epicarp browning occur when exposed to > 1ppm ethylene during short-term storage.

Table 3. Effect of packaging conditions and storage at $13^{\circ} \mathrm{C}$ on lightness $\left(\mathrm{L}_{0}\right)$ of eggplant compared to control samples.

\section{Storage time (days) $\quad$ Packaging conditions}

\begin{tabular}{ccccc}
\hline & Control & PPB & VPB \\
\cline { 2 - 5 } $\mathbf{0}$ & $91.20 \pm 0.85^{\mathrm{Aa}}$ & $91.20 \pm 0.85^{\mathrm{Aa}}$ & $91.20 \pm 0.85^{\mathrm{Aa}}$ \\
$\mathbf{5}$ & $89.50 \pm 0.28^{\mathrm{Aa}}$ & $90.00 \pm 0.28^{\mathrm{Aa}}$ & $90.45 \pm 0.49^{\mathrm{Aa}}$ \\
$\mathbf{1 0}$ & $86.15 \pm 2.03^{\mathrm{Bb}}$ & $88.60 \pm 0.42^{\mathrm{Ba}}$ & $90.05 \pm 0.64^{\mathrm{Aa}}$ \\
$\mathbf{1 5}$ & $81.35 \pm 1.06^{\mathrm{Cb}}$ & $87.55 \pm 0.21^{\mathrm{Ba}}$ & $86.20 \pm 0.99^{\mathrm{Ba}}$ \\
$\mathbf{2 0}$ & $71.90 \pm 0.14^{\mathrm{Db}}$ & $83.10 \pm 0.56^{\mathrm{Ca}}$ & $85.00 \pm 1.27^{\mathrm{Ba}}$ \\
\hline
\end{tabular}

Different capital letters in the same column indicate significant $(p<0.05)$ differences for each packaging condition. Lower case letters in the same row indicate significant $(p<0.05)$ differences between tested packaging treatments. 
Epicarp discoloration from dark purple to light purple of eggplant fruit packed at VPB conditions could be related to the continuous contact of fruit with the ethylene enclosed into the bag. Contact between eggplants and ethylene induces loss of anthocyanins pigments responsible for the purple color in this fruit (Noda et al., 2000; Concellón et al., 2007). Also, it could cause increases in $\mathrm{pH}$, diminution on acidity, and deterioration of internal and external appearance, which reduces overall quality.

Changes in visual appearance. Changes in visual appearance during storage are shown in Figure 2. After $5 \mathrm{~d}$ of storage, eggplant under the three conditions presented calyx browning, and this coloration increased until the end of storage, especially in the control samples and VPB condition.

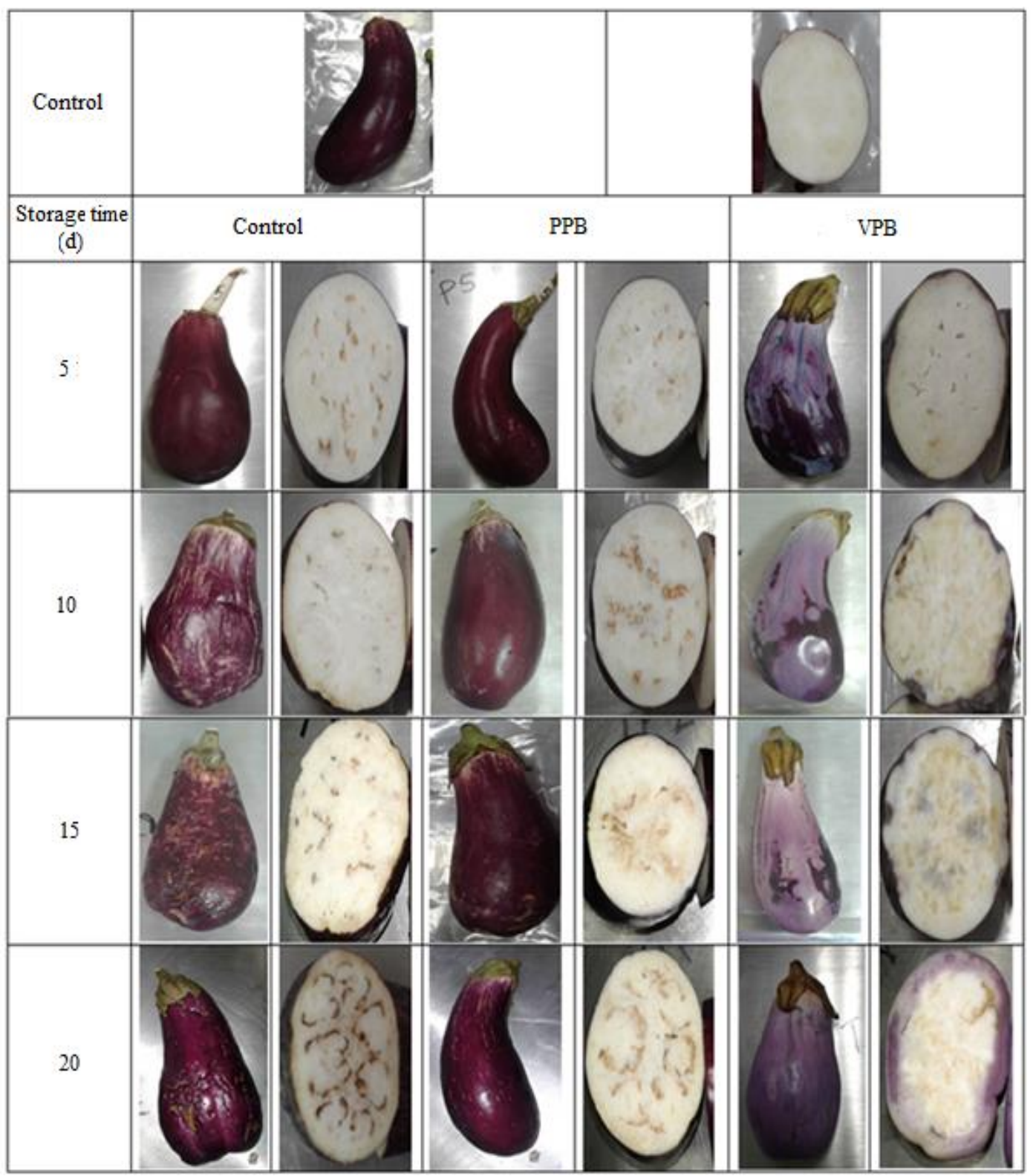

Figure 2. Evaluation of the internal and external physical appearance on eggplant packed at $13^{\circ} \mathrm{C}$ in bags of low-density polyethylene (LDPE) with perforations, vacuum packaged, and unpacked. 
These changes are associated with chilling injury (CI) symptoms, which were more noticeable in control samples after day 10, affecting internal and external appearance. As external signs, eggplant fruit presented a reduction of surface sheen, skin wrinkling, surface pitting, and spongy flesh, whereas pulp and seed browning was reported as internal CI symptom.

Browning of pulp tissue and seeds is also reported as CI sign (Concellón et al., 2004, Concellón et al., 2005), in that, PPO activity remained during storage at chilling temperatures in eggplants fruit cv Money Maker No. 2 (Concellón et al., 2004). Additionally, the response of eggplant fruit to stress conditions induced by low-temperature storages could result in fruit deterioration (Kacperska, 1997), which increased during storage at PPB treatment and control samples.

Epicarp discoloration was presented by VPB condition after $5 \mathrm{~d}$ of storage, reaching the complete fruit discoloration at the end of storage time. Eggplant fruit color turned from purple to light purple, it started from the calyx (upper section) toward the bottom (lower section) of the fruit. This process was accompanied by fruit softening. Additionally, from day 15 on, dispersed purple stains were noticeable in mesocarp tissue (Figure 2). Eggplant fruit discoloration was also reported by Concellón et al. (2007), for eggplants fruit cv Money Maker No. 2 after two days of storage and it was more noticeable at the upper section, similar as presented in this paper.

PPB conditions presented the best results, preserving internal and external visual appearance up to day 15 when chilling injury signs were detected. Similar results were reported by Concellón et al. (2004) for eggplants cv Money Maker No. 2 stored during $12 \mathrm{~d}$ at $10^{\circ} \mathrm{C}$. Moreover, eggplant fruit cv C029 lost its commercial quality since day ten due to undesirable changes in visual appearance.

Total phenolic content. The phenolic compounds (PC) content is presented in Table 4, as can be seen, phenolic compounds content increased after $5 \mathrm{~d}$ of storage, and then decreased until the end of storage period. This behavior was more noticeable at PPB treatment and control samples. Moreover, PC loss in control samples was progressive, whereas under PPB conditions PC content was constant until day 15 and then decreased, presenting no significant differences after 20d of storage between PPB treatment and control samples. VPB treatment presented a slight increase on PC at this period and could preserve them until day 10 , subsequently gradually decreased up to day 20. Nevertheless,

Table 4. Effect of packaging condition and storage at $13^{\circ} \mathrm{C}$ on total phenolic content (GAE mg. $\mathrm{kg}^{-1}$ d.b.) of eggplant.

\begin{tabular}{cccc}
\hline $\begin{array}{c}\text { Storage time } \\
\text { (days) }\end{array}$ & \multicolumn{3}{c}{$\begin{array}{c}\text { Packaging condition } \\
\text { (GAE mg.kg-1 d.b.) }\end{array}$} \\
\hline & Control & PPB & VPB \\
\cline { 2 - 4 } $\mathbf{0}$ & $4370 \pm 990^{\mathrm{Ca}}$ & $4370 \pm 990^{\mathrm{Ba}}$ & $4370 \pm 990^{\mathrm{Ba}}$ \\
$\mathbf{5}$ & $5050 \pm 120^{\mathrm{Ca}}$ & $5240 \pm 600^{\mathrm{Ba}}$ & $4530 \pm 200^{\mathrm{Ba}}$ \\
$\mathbf{1 0}$ & $4540 \pm 170^{\mathrm{Ca}}$ & $4600 \pm 80^{\mathrm{Ba}}$ & $4530 \pm 30^{\mathrm{Ba}}$ \\
$\mathbf{1 5}$ & $3170 \pm 130^{\mathrm{Ba}}$ & $4380 \pm 40^{\mathrm{Bc}}$ & $4000 \pm 200^{\mathrm{Bb}}$ \\
$\mathbf{2 0}$ & $1450 \pm 230^{\mathrm{Aa}}$ & $1200 \pm 150^{\mathrm{Aa}}$ & $2040 \pm 140^{\mathrm{Ab}}$ \\
\hline
\end{tabular}

Different capital letters in the same column indicate significant $(p<0.05)$ differences for each packaging condition. Lower case letters in the same row indicate significant $(p<0.05)$ differences between tested packaging treatments. 
this treatment showed the best results related to $\mathrm{PC}$ retention. It was found, during long term storage, PC losses could be superior to $50 \%$ and can be accompanied by pulp tissue browning or not. The decrease in PC content can be explained as a result of lignin deposition in fibers, xylem vessel, and seed coats (Concellón et al., 2012).

The PPB and VPB treatments presented interesting results related to the preservation of PC content in eggplant fruit until day 15, which could be employed as an alternative to extending the shelf life of this product, in that, PC content is one of the most important traits to maintain in eggplants. Polyphenols in fruit and vegetables are associated with health benefits, because of their chemical structure that can scavenge free radicals and inactivate other pro-oxidants (Nisha et al., 2009).

The results are corresponding to reported values by Concellón et al. (2012), for eggplant fruit cV Lucía, packed into perforated LDPE bags stored at $10^{\circ} \mathrm{C}$, which presented higher PC content after $14 \mathrm{~d}$ of storage than recently harvested (Table 4). The increase in PC content suggests an improvement in nutritional value and health benefits associated with antioxidants consumption.

Physicochemical properties and nutritional value of fruit and vegetables can be modified during postharvest handling, which is noticeable by undesirable changes in visual appearance. Although organoleptic properties are not enough parameters to determine the quality loss in eggplants, commercial acceptance is based on fruit appearance as a freshness parameter. Therefore, storage conditions accompanied by suitable packing materials must be designed to preserve overall quality in eggplant fruit.

\section{CONCLUSIONS}

Perforated polyethylene bags (PPB) treatment reduced chilling injury and caused a slight increase in phenolic compounds content of eggplant fruits cv C029 recently harvested, stored at $13^{\circ} \mathrm{C}$ during $15 \mathrm{~d}$. Even though vacuum-packed bags (VPB) treatment presented a reduction of pulp and seeds browning and higher preservation of phenolic compounds, it is not recommended for eggplant fruit packing under the studied conditions, due to undesirable changes on visual appearance. Remarkable variations on the external color of eggplant fruit are clear symptoms of commercial quality losses. Packing materials employed to extend the shelf life of eggplant fruit must regulate gas exchange between product and external environment as found and reported in this paper.

Conflict of interest: The authors declare that there is no conflict of interest.

\section{BIBLIOGRAPHIC REFERENCES}

Amanullah, S.; Jahangir, M.; Ikram, R.; Sajid, M.; Abbas, F.; Mallano, A. (2016). Aloe vera coating efficiency on shelf life of eggplants at differential storage temperatures. Journal of Northeast Agricultural University. 23 (4): 15-25. doi: 10.1016/S10068104(17)30003-X

AOAC - Association of Official Analytical Chemists. (2005). Official Method of Analysis, 18th ed. Washington, DC: Association of Official Analytical Chemists.

Berk,Z.(2009). Food processengineering and technology, $1^{\text {st }}$ ed. Burlington: Academic Press. 605p.

Cantwell, M.; Suslow, T. (2000). Eggplant: Recommendations for Maintaining Postharvest Quality. Recovered from http://afghanag.ucdavis. edu/a_horticulture/row-crops/eggplant/FS_Veg_ Eggplant_Postharvest_UCD_PHTC.pdf

Cao, G.; Sofic, E.; Prior, R. L. (1997). Antioxidant and prooxidant behavior of flavonoids: Structureactivity relationships. Free Radical Biology and Medicine. 22(5): 749-760. doi: 10.1016/S08915849(96)00351-6 
Concellón, A.; Añón, M.C.; Chaves, A.R. (2004). Characterization and changes in polyphenol oxidase from eggplant fruit (Solanum melongena L.) during storage at low temperature. Food Chemistry. 88(1): 17-24. doi: 10.1016/j.foodchem.2004.01.017

Concellón, A.; Añón, M.C.; Chaves, A.R. (2005). Effect of chilling on ethylene production in eggplant fruit. Food Chemistry. 92: 63-69. doi: 10.1016/j. foodchem.2004.04.048

Concellón, A.; Añón, M.C.; Chaves, A.R. (2007). Effect of low-temperature storage on physical and physiological characteristics of eggplant fruit (Solanum melongena L.) LWT- Food Science and Technology. 40: 389-396. doi: 10.1016/j. lwt.2006.02.004

Concellón, A.; Zaro, M.J.; Chaves, A.R.; Vicente, A.R. (2012). Changes in quality and phenolic antioxidants in dark purple American eggplant (Solanum melongena L. Cv. Lucía) as affected by storage at $0^{\circ} \mathrm{C}$ and $10^{\circ} \mathrm{C}$. Postharvest Biology and Technology. 66: 35-41. doi: 10.1016/j.postharvbio.2011.12.003

Das, J.R.; Bhat, S.G.; Gowda, L.R. (1997). Purification and characterization of a polyphenol oxidase from the Kew cultivar of Indian pineapple fruit. Journal of Agricultural and Food Chemistry. 45: 2031-2035. doi: 10.1021/jf9607674

Díaz-Pérez, J.C. (1998). Transpiration rates in eggplant fruit as affected by fruit and calyx size. Postharvest Biology and Technology. 13: 45-49. doi: 10.1016/ S0925-5214(97)00078-1

FAO - Food and Agriculture Organization of the United Nations (2017). Production/Yield/ Consumption quantities of Eggplants (aubergines) in World. Recovered from http://www.fao.org/faostat/ en/\#data/QC

Francis, F. J. (2000). Wiley Encyclopedia of Food Science and Technology. Vol. 1, $2^{\text {nd }}$ ed., USA: Wiley. 2724 p.

García-Salas, P.; Gómez-Caravaca, A.M.; Morales-Soto, A.; Segura-Carretero, A.; Fernández-Gutiérrez, A. (2014). Identification and quantification of phenolic compounds in diverse cultivars of eggplant grown in different seasons by high-performance liquid chromatography coupled to diode array detector and electrospray-quadrupole-time of flight-mass spectrometry. Food Research International. 57: 114122. doi: 10.1016/j.foodres.2014.01.032
Gürbüz, N.; Uluişik, S.; Frary, A.; Frary, A.; Doğanlar, S. (2018). Health benefits and bioactive compounds of eggplant. Food Chemistry. 268: 602-610. doi: 10.1016/j.foodchem.2018.06.093

Huang, H.Y.; Chang, C.K.; Tso, T.K.; Huang, J.J.; Chang, W.W.; Tsai, W.C. (2004). Antioxidant activities of various fruits and vegetables produced in Taiwan. InternationalJournalofFoodScienceandNutrition.55: 423-429. doi: 10.1080/09637480412331324695

Jha, S. N.; Matsuoka, T.; Miyauchi, K. (2002). Surface Gloss and Weight of Eggplant during Storage. Biosystems Engineering. 81 (4): 407-412.

Kader, A. (2002). Biología y tecnología poscosecha: Un panorama. In Kader, A. \& Pelayo-Saldivar, C. (Eds.). Tecnología Postcosecha de Cultivos Hortofrutícolas. pp. 43-54. Davis CA: University of California.

Kacperska, A. (1997). Ethylene synthesis and a role in plant responses to different stressors. In: Kanellis, A. K., Chang, C., Klee, H., Bleecker, A. B., Pech, J. C., \& Grierson, D. (Eds.). Biology and biotechnology of the plant hormone ethylene. pp. 207-216. Netherlands: Kluwer Academic Publishers. doi: 10.1007/978-94011-5546-5_27

Manach, C.; Scalbert, A.; Morand, C.; Rémésy, C.; Jiménez, L. (2004). Polyphenols: food sources and bioavailability. American Journal of Clinical Nutrition. 79: 727-747.

Massolo, J.; Concellón, A.; Chaves, A.; Vicente, A. (2011). 1-Methylcyclopropene (1-MCP) delays senescence, maintains quality and reduces browning of nonclimacteric eggplant (Solanum melongena L.) fruit. Postharvest Biology and Technology. 59: 10-15. doi: 10.1016/j.postharvbio.2010.08.007

Matheis, G.; Belitz, H. (1977). Studies on enzymatic browning of potatoes (Solanum Tuberosum). Lebensmittel-Untersuchung und -Forschung. 163: 191-195.

Mishra, B.B.; Gautam, S.; Sharma, A. (2013). Free phenolics and polyphenol oxidase (PPO): The factors affecting post-cut browning in eggplant (Solanum melongena). Food Chemistry. 139: 105114. doi: 10.1016/j.foodchem.2013.01.074

Montero-Calderón, M.; Cerdas-Araya, M. (2012). Postharvest physiology and storage. In Siddiq M. 
(Ed.). Tropical and Subtropical Fruits Postharvest physiology. Processing and Packaging. pp. 17-33. USA: Wiley-Blackwell.

Muñoz-Pina, S.; Ros-Lis, J.; Argüelles, A.; MartínezMáñez, R.; Andrés, A. (2020). Influence of the functionalisation of mesoporous silica material UVM-7 on polyphenol oxidase enzyme capture and enzymatic browning. Food Chemistry. 310: 125741, 1-8.

Nicolas, J.; Richard-Forget, F.; Goupy, P.; Amiot, M. J.; Aubert, S. (1994). Enzymatic browning reactions in apple and apple products. Critical Reviews in Food Science and Nutrition. 34 (2): 109-157. doi: $10.1080 / 10408399409527653$

Nisha, P.; Nazar, A.; Jayamurthy. P. (2009). A comparative study on antioxidant activities of different varieties of Solanum melongena L. Food and Chemical Toxicology. 47: 2640-2644. doi: 10.1016/j. fct.2009.07.026

Noda, Y.; Kneyuki, T.; Igarashi, K.; Mori, A.; Packer, L. (2000). Antioxidant activity of nasunin, an anthocyanin in eggplant peels. Toxicology. 148: 119123. doi: 10.1016/S0300-483X(00)00202-X

Pérez-Gilabert, M.; García-Carmona, F. (2000). Characterization of catecholase and cresolase activities of eggplant polyphenol oxidase. Journal of Agricultural and Food Chemistry. 48(3): 695-700. doi: 10.1021/jf990292r

Sakamura, S.; Obata, Y. (1963). Anthocyanase and anthocyaninsoccurringineggplant,Solanummelongena L. Agricultural and Biological Chemistry. 27(2): 121127. doi: $10.1080 / 00021369.1963 .10858070$

Singh, R.; Singh, N. (2005). Quality of packaged foods. In: J. Han, J.H. (Ed.), Innovations in Food packaging. pp. 2444. USA: Elsevier Academic Press.

Stommel, J.R.; Whitaker, B.D. (2003). Phenolic acid content and composition of eggplant fruit in a germplasm core subset Journal of the American Society for Horticultural Science. 128: 704-710.

Sudheesh, S.; Sandhya, C.; Koshy, A.S.; Vijayalakshmi, N. (1999). Antioxidant activity of flavonoids from Solanum melongena L. Phytotherapy Research 13: 393-396. doi: 10.1002/(SICI) 1099-1573 (199908/09)13:5<393::AID-PTR474>3.0.C0;2-8
Sukprasansap, M.; Sridonpai, P.; Phiboonchaiyanan, P.P. (2019). Eggplant fruits protect against DNA damage and mutations. Mutat Res Fund Mol Mech Mutagen. 813: 39-45.

Yamaguchi, S.; Matsumoto, K.; Koyama, M.; Tian, S.; Watanabe, M.; Takahashi, A.; Miyatake, K.; Nakamura, K. (2019). Antihypertensive effects of orally administered eggplant (Solanum melongena) rich in acetylcholine on spontaneously hypertensive rats. Food Chemistry. 276: 376-382. doi: 10.1016/j. foodchem.2018.10.017

Zaro, M.J.; Chaves, A.; Vicente, A.R.; Concellón, A. (2014). Changes in bioactive compounds and response to postharvest storage conditions in purple eggplants as affected by fruit developmental stage. Postharvest Biology and Technology. 96: 110-117. doi: 10.1016/j. postharvbio.2014.05.012 